\title{
Hyperglycemia induces insulin resistance on angiotensinogen gene expression in diabetic rat kidney proximal tubular cells
}

\author{
S-L Zhang, X Chen, T-J Hsieh, M Leclerc ${ }^{1}$, N Henley ${ }^{1}$, A Allidina, \\ J-P Hallé ${ }^{1}$, M G Brunette ${ }^{1}$, J G Filep ${ }^{1}$, S-S Tang ${ }^{2}$, J R Ingelfinger ${ }^{2}$ \\ and J S D Chan
}

Université de Montréal, Centre hospitalier de I'Université de Montréal (CHUM)-Hotel-Dieu, Centre de Recherche, Pavillon Masson, 3850 Saint-Urbain Street,
Montréal, Quebec, Canada H2W 1T8
${ }^{1}$ Maisonneuve-Rosemont Hospital, Research Center, 5415 boul. De l'Assomption, Montréal, Quebec, Canada H1T 2M4
${ }^{2}$ Harvard Medical School, Massachusetts General Hospital, Pediatric Nephrology Unit, 15 Parkman Street, WAC 709, Boston, Massachusetts 02114-3117,
USA
(Requests for offprints should be addressed to J S D Chan, Université de Montréal, CHUM- Hôtel-Dieu, Pavillon Masson, 3850 Saint-Urbain St, Montréal,
Quebec, Canada H2W 1T8; Email: john.chan@umontreal.ca)

\begin{abstract}
Clinical and animal studies have shown that treatment with angiotensin-converting enzyme (ACE) inhibitors or angiotensin II (Ang II) receptor antagonists slows the progression of nephropathy in diabetes, indicating that Ang II plays an important role in its development. We have reported previously that insulin inhibits the stimulatory effect of high glucose levels on angiotensinogen (ANG) gene expression in rat immortalized renal proximal tubular cells (IRPTCs) via the mitogen-activated protein kinase (p44/42 MAPK) signal transduction pathway. We hypothesize that the suppressive action of insulin on ANG gene expression might be attenuated in renal proximal tubular cells (RPTCs) of rats with established diabetes.

Two groups of male adult Wistar rats were studied: controls and streptozotocin (STZ)-induced diabetic rats at 2, 4, 8 and 12 weeks post-STZ administration. Kidney proximal tubules were isolated and cultured in either normal glucose (i.e. $5 \mathrm{mM}$ ) or high glucose (i.e. $25 \mathrm{mM}$ ) medium to determine the inhibitory effect of insulin on
\end{abstract}

ANG gene expression. Immunoreactive rat ANG (IRrANG) in culture media and cellular ANG mRNA were measured by a specific radioimmunoassay and reverse transcription-polymerase chain reaction assay respectively. Activation of the p44/42 MAPK signal transduction pathway in rat RPTCs was evaluated by p44/42 MAPK phosphorylation employing a PhosphoPlus p44/42 MAPK antibody kit.

Insulin $\left(10^{-7} \mathrm{M}\right)$ inhibited the stimulatory effect of high glucose levels on IR-rANG secretion and ANG gene expression and increased p44/42 MAPK phosphorylation in normal rat RPTCs. In contrast, it failed to affect these parameters in diabetic rat RPTCs.

In conclusion, our studies demonstrate that hyperglycaemia induces insulin resistance on ANG gene expression in diabetic rat RPTCs by altering the MAPK signal transduction pathway.

Journal of Endocrinology (2002) 172, 333-344

\section{Introduction}

Experimental studies have shown that incubation of murine proximal tubular cells in high-glucose (i.e. $25 \mathrm{mM}$ ) medium or in the presence of high angiotensin II (Ang II) levels (i.e. $>10^{-8} \mathrm{M}$ ) induces cellular hypertrophy and extracellular matrix protein synthesis (Wolf \& Neilson 1990, Ziyadeh et al. 1990, Wolf et al. 1991a,b, 1993a,b, Rocco et al. 1992). Clinical studies have also revealed that intensive insulin therapy or treatment with angiotensin-converting enzyme (ACE) inhibitors or Ang II receptor antagonists in patients with insulin-dependent diabetic mellitus delays the onset and slows the progression of nephropathy (Bakris 1993, Lewis et al. 1993, Gandhi et al. 1996, Ichikawa 1996, Ruilope 1997). These investigations indicate that hyperglycaemia and reninangiotensin system (RAS) activation are the two important determinants in the pathogenesis of diabetic nephropathy (Maurer 1994, Wolf \& Thaiss 1995). The molecular mechanism(s) of the beneficial effects of insulin therapy and ACE inhibitors or Ang II receptor antagonists, however, is not completely understood.

In addition to the well-characterized systemic RAS, the presence of a local intrarenal RAS has now been generally accepted. The mRNA components of the RAS, including angiotensinogen (ANG), renin, ACE and Ang II receptors $\left(\mathrm{AT}_{-}{ }_{1}\right.$ and $\mathrm{AT}_{-}-_{2}$ subtypes) are expressed in mouse and rat immortalized renal proximal tubular cells (IRPTCs) 
(Ingelfinger et al. 1990, 1999, Wolf \& Neilson 1993, Chen et al. 1994, Loghman-Adham et al. 1997). We have reported that ANG protein is synthesized and secreted from rat IRPTCs (Wang et al. 1998, Umezu et al. 2000), providing evidence that intrarenal Ang II is derived from ANG synthesized within renal proximal tubular cells (RPTCs) in vivo.

We have recently demonstrated that high glucose levels (i.e. $25 \mathrm{mM}$ ) stimulated ANG gene expression and induced hypertrophy in IRPTCs (Zhang et al. 1999a, 2001). This stimulatory effect of glucose was blocked by the addition of the inhibitors of aldose reductase (i.e. Tolrestat), protein kinase $\mathrm{C}$ (PKC) (i.e. staurosporine or H-7), and ACE (i.e. captopril or perindopril) or Ang II (AT-1) receptor antagonist (i.e. Losartan) (Zhang et al. 1999a, 2001). These studies demonstrated that high glucose levels stimulate renal ANG gene expression via the de novo diacylglycerol (DAG) and PKC signal transduction pathways, subsequently activating the local renal RAS in vivo. The local formation of Ang II may play an important (i.e. autocrine) role in the induction of proximal tubular cell hypertrophy in diabetes.

Recently, we reported that insulin inhibited the stimulatory effect of high glucose levels on ANG secretion, ANG messenger RNA (mRNA) and ANG gene expression in IRPTCs (Zhang et al. 1999b, Chen et al. 2001). This suppressive action of insulin is blocked by an inhibitor of mitogen-activated protein kinase (MAPK) but not by an inhibitor of phosphatidylinositol 3-kinase (PI3K), suggesting that the inhibitory effect of insulin on renal ANG gene expression is mediated, at least in part, via the MAPK signal transduction pathway. In the present studies, we investigated whether the inhibitory effect of insulin on ANG gene expression is attenuated in RPTCs isolated from rats with established diabetes. Our studies showed that insulin suppressed the stimulatory action of high glucose levels on ANG gene expression and increased p44/42 MAPK phosphorylation in control non-diabetic rat RPTCs. In contrast, insulin had no influence on ANG gene expression and p44/42 MAPK phosphorylation in diabetic rat RPTCs.

\section{Materials and Methods}

$\mathrm{D}(+)-G$ lucose, D-mannitol, insulin, collagenase (type IV), bovine serum albumin (fraction $\mathrm{V}$ ) and streptozotocin (STZ) were purchased from Sigma-Aldrich Chemicals Canada Ltd (Oakville, Ontario, Canada). Percoll was obtained from Amersham Pharmacia Biotech (Baie d'Urfe, Quebec, Canada). Normal glucose (5 mM) Dulbecco's modified Eagle's medium (DMEM, cat. \#12320) was purchased from Life Technologies Inc. (Burlington, Ontario, Canada). PD 98059 and Wortmannin were purchased from Calbiochem Inc. (La Jolla, CA, USA).

Gamma- $\left[{ }^{32} \mathrm{P}-\mathrm{ATP}\right](3000 \mathrm{Ci} / \mathrm{mol})$ and $\mathrm{Na}^{125} \mathrm{I}$ were bought from Dupont, New England Nuclear (Boston,
MA, USA). Oligonucleotides were synthesized by Life Technologies Inc. Restriction and modifying enzymes were acquired from Life Technologies Inc., BoehringerMannheim (Dorval, Quebec, Canada), or Amersham Pharmacia Biotech.

The PhosphoPlus p44/42 MAPK antibody kit from New England Biolabs, Inc. (Mississauga, Ontario, Canada) was used for rapid analysis of the p44/42 MAPK (Thr 202/Tyr 204) phosphorylation status in the MAPK cascade.

\section{Animals}

Male Wistar rats (200-250 g) from Charles River Inc. (St-Constant, Quebec, Canada) were divided into 2 groups (6 rats per group) after acclimatization for 3 days: 1$)$ vehicle-injected controls $(10 \mathrm{mM}$ sodium citrate buffer, $\mathrm{pH} 4 \cdot 0$, in $0.9 \%$ saline, i.p.) and 2) STZ-induced diabetics (STZ-D). Vehicle and STZ $(65 \mathrm{mg} / \mathrm{kg}$ dissolved in $10 \mathrm{mM}$ sodium citrate buffer, $\mathrm{pH} 4 \cdot 0$, in $0 \cdot 9 \%$ saline, i.p.) were administered after overnight fasting. Forty-eight hours after administration of STZ, blood was assayed for glucose levels with a Side-Kick Glucose Analyzer (Model 1500, Interscience, Markham, Ontario, Canada). Rats with blood glucose $>400 \mathrm{mg} / \mathrm{dl}$ or $>20 \mathrm{mM}$ were studied. All animals were allowed free access to rat chow and water. Animals were anaesthetized and killed by decapitation. Twenty-four hours prior to killing, the animals were individually housed in metabolic cages. Urine samples were collected and assayed for glucose and urea (performed by the Biochemistry Laboratory, Maisonneuve-Rosemont Hospital) and ketone levels (Keto-Diastix, Bayer Inc., Healthcare Division, Toronto, Ontario, Canada). Blood samples were collected for the measurement of plasma glucose and creatinine levels (Biochemistry Laboratory, Maisonneuve-Rosemont Hospital). Plasma and urinary ANG levels were quantified with a specific radioimmunoassay (RIA) for rat ANG as we described previously (Wang et al. 1998). Kidneys were removed immediately after death. One kidney from each rat was taken for total RNA extraction. The other kidneys were pooled together (i.e. from 6 rats) and then used for proximal tubule isolation. All methods of animal care and killing were approved by the Animal Care Committee of Maisonneuve-Rosemont Hospital. Each experiment was repeated at least three times.

\section{Isolation and culture of rat RPTCs}

The renal cortex was separated from the medulla and cut into small fragments under sterile conditions. Proximal tubules were isolated according to the method of Vinay et al. (1981) with slight modifications. Briefly, cortical fragments were washed with DMEM:Ham F-12 medium containing $0 \cdot 2 \%$ bovine serum albumin (BSA), penicillin $(100 \mathrm{U} / \mathrm{ml})$ and streptomycin $(100 \mu \mathrm{g} / \mathrm{ml})$ 
pre-equilibrated with $95 \% \mathrm{O}_{2} / 5 \% \mathrm{CO}_{2}$. The cortical fragments were then digested with agitation for $30 \mathrm{~min}$ at $37^{\circ} \mathrm{C}$ in DMEM:Ham F-12 medium containing collagenase $(1 \mathrm{mg} / \mathrm{ml})$. After digestion, the mixtures were passed once through a metal filter (60 mesh), and the tubular suspensions were washed twice with DMEM:Ham F-12 medium. Finally, the tubular suspensions were suspended in culture media containing $42 \%$ Percoll preequilibrated with $95 \% \mathrm{O}_{2} / 5 \% \mathrm{CO}_{2}$ and centrifuged at $28000 \times \boldsymbol{g}$ without braking for $30 \mathrm{~min}$ at $4{ }^{\circ} \mathrm{C}$. Three bands were observed after centrifugation: 1) an upper band enriched with distal tubules, 2) a middle band enriched with glomeruli, and 3) a lower band enriched with proximal tubules. The band of enriched proximal tubules was carefully isolated with a syringe and washed 3 times in DMEM:Ham F-12 medium. Proximal tubular cells were characterized by their histological appearance as described previously (Vinay et al. 1981). This procedure yielded a highly purified preparation of proximal tubules (>97\% by microscopy) and viability was $>95 \%$ (determined by exclusion of trypan blue).

Freshly-isolated proximal tubules from normal and STZ-D rats were cultured in normal glucose $(5 \mathrm{mM})$ or high glucose $(25 \mathrm{mM})$ DMEM containing $5 \%$ fetal bovine serum (FBS) and 5 factors (insulin, $5 \mu \mathrm{g} / \mathrm{ml}$; transferrin, $5 \mu \mathrm{g} / \mathrm{ml}$; hydrocortisone, $0.05 \mathrm{mM}$; prostaglandin $\mathrm{E}_{1}$, $25 \mathrm{ng} / \mathrm{ml}$ and epidermal growth factor (EGF), $10 \mathrm{ng} / \mathrm{ml}$ ) as described by Chung et al. (1982). After 3 days in culture, rat RPTCs attached to the Petri dish as a monolayer were harvested by trypsinization and re-plated onto 6-well plates in $5 \mathrm{mM}$ glucose DMEM or $25 \mathrm{mM}$ glucose DMEM containing 5\% FBS and the five factors. Prior to the experiments, the RPTCs were synchronized overnight in $5 \mathrm{mM}$ or $25 \mathrm{mM}$ glucose serum-free medium (no supplementation with 5 factors). Then, the RPTCs were incubated in normal glucose plus $20 \mathrm{mM}$ D-mannitol or high glucose DMEM plus 1\% depleted FBS (dFBS) in the absence or presence of insulin $\left(10^{-7} \mathrm{M}\right)$. After 24 hours of incubation, the media were collected and assayed for immunoreactive rat ANG (IR-rANG). The cells were harvested and extracted for total RNA with Trizol reagent as we described previously (Zhang et al. 1999a,b, 2001). Total RNAs were used to quantify the mRNA of ANG and $\beta$-actin by reverse transcription-polymerase chain reaction (RT-PCR) (Zhang et al. 1999a,b, 2001).

The dFBS (depleted of endogenous steroid and thyroid hormones) was prepared by incubation with $1 \%$ activated charcoal and 1\% AG 1 X 8 ion-exchange resin (Bio-Rad Laboratoires Inc., Richmond, CA, USA) for 16 to 24 hours at room temperature as described by Samuels et al. (1979).

\section{RIA for rat $A N G$}

The RIA for rat ANG developed in our laboratory (J S D C) has been described previously in detail (Wang et al. 1998). Purified rat plasma ANG (greater than $90 \%$ pure, as analysed by polyacrylamide gel electrophoresis containing sodium dodecyl sulphate (SDS-PAGE)) and iodinated rANG were used as hormone standard and tracer respectively. This RIA is specific for intact (62 to $65 \mathrm{kDa}$ ) rANG and has no cross-reactivity with pituitary hormone preparations or other rat plasma proteins (Wang et al. 1998). The lower limit of detection for the RIA is approximately $1 \mathrm{ng}$ rANG. The intra-assay and interassay coefficients of variation were $9 \%(n=10)$ and $14 \%(n=10)$ respectively.

\section{Phosphorylation of p44/42 MAPK in RPTCs}

The effect of insulin on activation of the p44/42 MAPK signal transduction pathway in RPTCs was evaluated by p44/42 MAPK phosphorylation, employing the PhosphoPlus p44/42 MAPK antibody kit (Zhang et al. 1999b). Briefly, RPTCs were plated in $5 \mathrm{mM}$ or $25 \mathrm{mM}$ glucose DMEM containing 10\% FBS and synchronized in $5 \mathrm{mM}$ glucose medium for 24 hours. Subsequently, the cells were incubated in medium containing $5 \mathrm{mM}$ glucose plus $20 \mathrm{mM}$ D-mannitol, or $25 \mathrm{mM}$ glucose in the absence or presence of PD $98050\left(10^{-5} \mathrm{M}\right)$ for $15 \mathrm{~min}$. Then, insulin $\left(10^{-7} \mathrm{M}\right)$ was added and the cells were incubated for another $10 \mathrm{~min}$. They were lysed in $300 \mu \mathrm{l}$ lysis buffer (62.5 mM Tris- $\mathrm{HCl}, \mathrm{pH} 6 \cdot 8$, containing 2\% SDS (wt/ vol), $10 \%$ glycerol, $50 \mathrm{mM}$ dithiothreitol and $0 \cdot 1 \%$ bromophenol blue (wt/vol)), before being transferred into Eppendorf tubes. The cell lysates were sonicated for $20 \mathrm{~s}$ and heated at $95{ }^{\circ} \mathrm{C}$ for $5 \mathrm{~min}$, and then centrifuged at $12000 \times \boldsymbol{g}$ for $10 \mathrm{~min}$ at $4^{\circ} \mathrm{C}$. Small aliquots $(20-50 \mu \mathrm{l})$ of the supernatants were subjected to $10 \%$ SDS-PAGE and then transferred onto a PVDF membrane (Hybond-P, Amersham Pharmacia Biotech). The membrane was first blotted for phosphorylated p44/42 MAPK and then re-blotted for total p44/42 MAPK with the PhosphoPlus p44/42 MAPK antibody kit. The relative densities of phosphorylated p44/42 MAPK and total p44/42 MAPK bands were determined with a computerized laser densitometer.

\section{ANG mRNA expression in RPTCs}

To study the effect of glucose and insulin on ANG mRNA expression, RPTCs were incubated in $5 \mathrm{mM}$ glucose medium plus $20 \mathrm{mM}$ D-mannitol, $25 \mathrm{mM}$ glucose medium, or $25 \mathrm{mM}$ glucose medium plus insulin $\left(10^{-7} \mathrm{M}\right)$ in the absence or presence of PD 98050 $\left(10^{-5} \mathrm{M}\right)$ for 24 hours. At the end of the incubation period, the cells were collected, and total RNA was isolated with Trizol reagent (Life Technologies Inc.) according to the manufacturer's protocol. Total RNA was subjected to RT-PCR to quantify the amount of ANG mRNA expressed in RPTCs (Zhang et al. 1999a,b; 2001). Briefly, $1 \mu \mathrm{g}$ aliquot of total RNA was used for cDNA 
Table 1 Biochemical data of non-diabetic (control) and streptozotocin-induced diabetic (STZ) rats killed after 2, 4, 8 and 12 weeks. Each measurement represents the mean \pm S.D. of 18 animals

\begin{tabular}{|c|c|c|c|c|c|}
\hline & $\begin{array}{l}\text { Plasma glucose } \\
(\mathrm{mM})\end{array}$ & $\begin{array}{l}\text { Plasma creatine } \\
(\mathrm{mM})\end{array}$ & $\begin{array}{l}\text { Urinary glucose } \\
(\mathrm{mM})\end{array}$ & $\begin{array}{l}\text { Urinary urea } \\
(\mathrm{mM})\end{array}$ & $\begin{array}{l}\text { Urinary ketone } \\
(\mathrm{mM})\end{array}$ \\
\hline Control (2 wks) & $5 \cdot 43 \pm 0 \cdot 33$ & $49 \cdot 5 \pm 3 \cdot 15$ & $0 \cdot 13 \pm 0 \cdot 05$ & $412 \cdot 33 \pm 70 \cdot 99$ & $<0.5$ \\
\hline STZ (2 wks) & $24 \cdot 42 \pm 2 \cdot 03^{* * *}$ & $46 \cdot 0 \pm 3 \cdot 85$ & $372 \cdot 0 \pm 69 \cdot 1^{* * *}$ & $407 \cdot 6 \pm 188 \cdot 27$ & $\leq 0.5$ \\
\hline STZ (4 wks) & $26 \cdot 97 \pm 1 \cdot 3^{* * *}$ & $61 \cdot 75 \pm 4 \cdot 35$ & $344 \cdot 7 \pm 42 \cdot 6^{* * *}$ & $292 \cdot 0 \pm 67 \cdot 31$ & $\leq 0.5$ \\
\hline Control (8 wks) & $5 \cdot 5 \pm 0 \cdot 35$ & $82 \cdot 5 \pm 18 \cdot 75$ & $0 \cdot 07 \pm 0.05$ & $307 \cdot 6 \pm 76 \cdot 66$ & $<0.5$ \\
\hline STZ (8 wks) & $24.97 \pm 2 \cdot 5^{\star \star *}$ & $59 \cdot 83 \pm 16 \cdot 18$ & $253 \cdot 7 \pm 16 \cdot 2^{* * *}$ & $280 \cdot 33 \pm 56 \cdot 55$ & $\leq 0.5$ \\
\hline
\end{tabular}

Values in control rats are compared with diabetic rats; ${ }^{* * *} P \leq 0 \cdot 005$

synthesis by employing the Super-Script preamplication system, following the protocol described by the supplier (Life Technologies Inc.). Then, $2 \mu \mathrm{l}$ of the cDNA reaction mixture were used to amplify the rat ANG cDNA and $\beta$-actin cDNA fragments using the PCR-core kit according to the protocol of the supplier (Boehringer-Mannheim Inc.). The forward primer $5^{\prime}$ CCT CGC TCT CTG GAC TTA TC 3', and the reverse primer 5' CAG ACA CTG AGG TGC TGT TG $3^{\prime}$, corresponding to the nucleotide sequences $\mathrm{N}+676$ to $\mathrm{N}+695$ and $\mathrm{N}+882$ to $\mathrm{N}+901$ of rat cDNA (Ohkubo et al. 1983) were utilized for PCR. Furthermore, primers specific for rat $\beta$-actin (Nudel et al. 1983) (forward and reverse primers $5^{\prime}$ ATG CCA TCC TGC GTC TGG ACC TGG C $3^{\prime}$ and 5' AGC ATT TGC GGT GCA CGA TGG AGG G 3' corresponding to the nucleotide sequences $\mathrm{N}+155$ to $\mathrm{N}+139$ of exon 3 and $\mathrm{N}+115$ to $\mathrm{N}+139$ of exon 5 of rat $\beta$-actin) were used in another PCR as internal controls. The amplification cycles were $45 \mathrm{~s}$ at $94{ }^{\circ} \mathrm{C}, 45 \mathrm{~s}$ at $60{ }^{\circ} \mathrm{C}$ and $90 \mathrm{~s}$ at $72{ }^{\circ} \mathrm{C}$ in a Perkin-Elmer Cetus 9600 thermocycler (Perkin-Elmer Cetus, Norwalk, CT, USA). The PCR cycles for the amplication of ANG and $\beta$-actin mRNA were 35 and 30 respectively. The RT-PCR mixtures were separated on $1.5 \%$ agarose gel and transferred onto a Hybond XL nylon membrane (Amersham Pharmacia Biotech). Subsequently, ${ }^{32}$ P-labelled oligonucleotides 5' GAG GGG GTC AGC ACG GAC AGC ACC $3^{\prime}$ and $5^{\prime}$ TCC TGT GGC ATC CAT GAA ACT ACA TTC $3^{\prime}$ corresponding to the nucleotide sequences $\mathrm{N}+775$ to $\mathrm{N}+798$ of the rat ANG cDNA (Ohkubo et al. 1983) and nucleotides $N+9$ to $N+35$ of exon 4 of rat $\beta$-actin (Nudel et al. 1983), respectively, served to hybridize the PCR products on the membrane. Finally, the membrane was washed and subjected to autoradiography. The relative densities of the PCR bands were determined with a computerized laser densitometer.

\section{Statistical analysis}

Three to four separate experiments were performed per protocol, and each treatment group was assayed in triplicate. The data were analysed by Student's $t$-test or analysis of variance (ANOVA). A probability level of $P \leq 0.05$ was considered to be statistically significant.

\section{Results}

\section{Physical and biochemical data of whole animals}

Figure 1 and Table 1 show the results of physical and biochemical data in control and STZ-D rats at the time of killing. It is apparent that STZ-D rats had significantly higher plasma and urinary glucose levels and higher kidney to body weight ratios which increased with time when compared with the controls. There were no significant differences in plasma creatinine and urinary urea and ketone excretion between control and STZ-D rats (Table 1).

\section{Plasma and urinary IR-rANG levels}

Figure 2 shows the results of plasma and urinary (i.e. 24-hour collection) IR-rANG levels in control and STZ-D rats at the time of death. Both plasma and urinary IR-rANG levels were increased in STZ-D rats compared with the controls, but these levels did not reach statistical significance.

\section{Expression of kidney ANG $m R N A$ levels}

Figure 3 illustrates the results of Northern blot analysis of whole kidney ANG mRNA and $\beta$-actin mRNA in control and STZ-D rats. Renal ANG to $\beta$-actin mRNA ratios were not statistically different between control and STZ-D rats.

Effect of glucose and insulin on IR-rANG secretion in rat RPTCS

IR-rANG secretion was increased (150\%) in control rat RPTCs with high glucose $(25 \mathrm{mM})$ medium compared 
A.

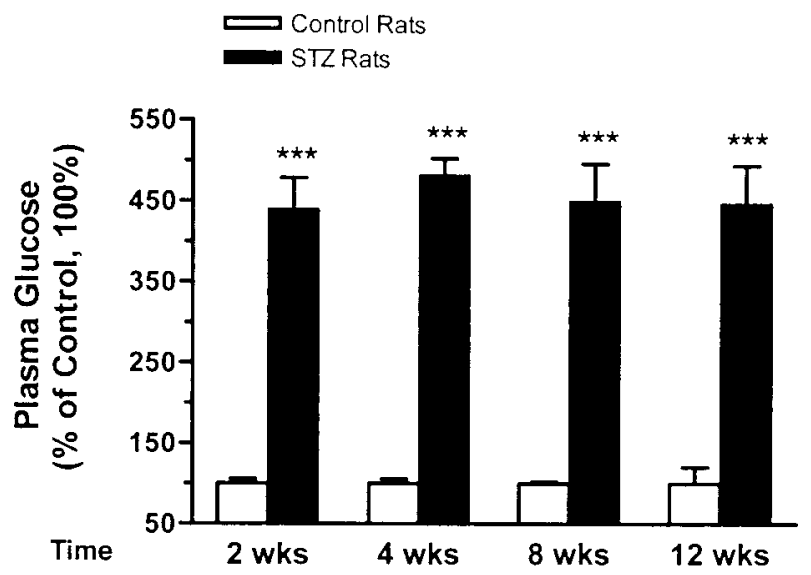

B.

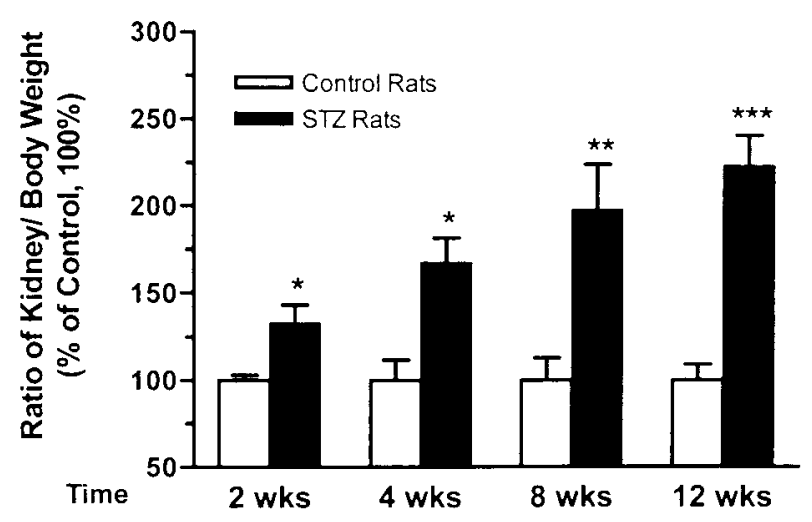

(POST-STZ ADMINISTRATION)

Figure 1 (A) Plasma glucose levels and (B) kidney to body weight ratios in control and streptozotocin-induced diabetic (STZ) rats. Values in control rats are expressed as $100 \%$. Each point represents the mean \pm S.D. of 18 animals. ${ }^{*} P \leq 0 \cdot 05,{ }^{*} P \leq 0 \cdot 01$, ${ }_{* * *} P \leq 0.005$ compared with controls.

with normal glucose levels $(5 \mathrm{mM})(P \leq 0 \cdot 05)$ (Figs 4 and $5 \mathrm{~A})$. The addition of insulin to the culture medium abolished the high glucose-stimulated secretion of IR-rANG in control rat RPTCs.

In contrast, high glucose levels $(25 \mathrm{mM})$ did not increase IR-rANG secretion in STZ-D rat RPTCs, compared with normal glucose levels (Figs 4 and 5B). The addition of insulin to the culture medium had no significant effect on IR-rANG secretion in diabetic rat RPTCs. Furthermore, the addition of PD 98059 reversed the inhibitory action of insulin on IR-rANG secretion in control RPTCs (Fig. 5A) but had no influence on diabetic rat RPTCs. Moreover, the addition of Wortmannin did not modify the effect of insulin on IR-rANG secretion from control (Fig. 5A) and diabetic rat RPTCs (Fig. 5B).
A.
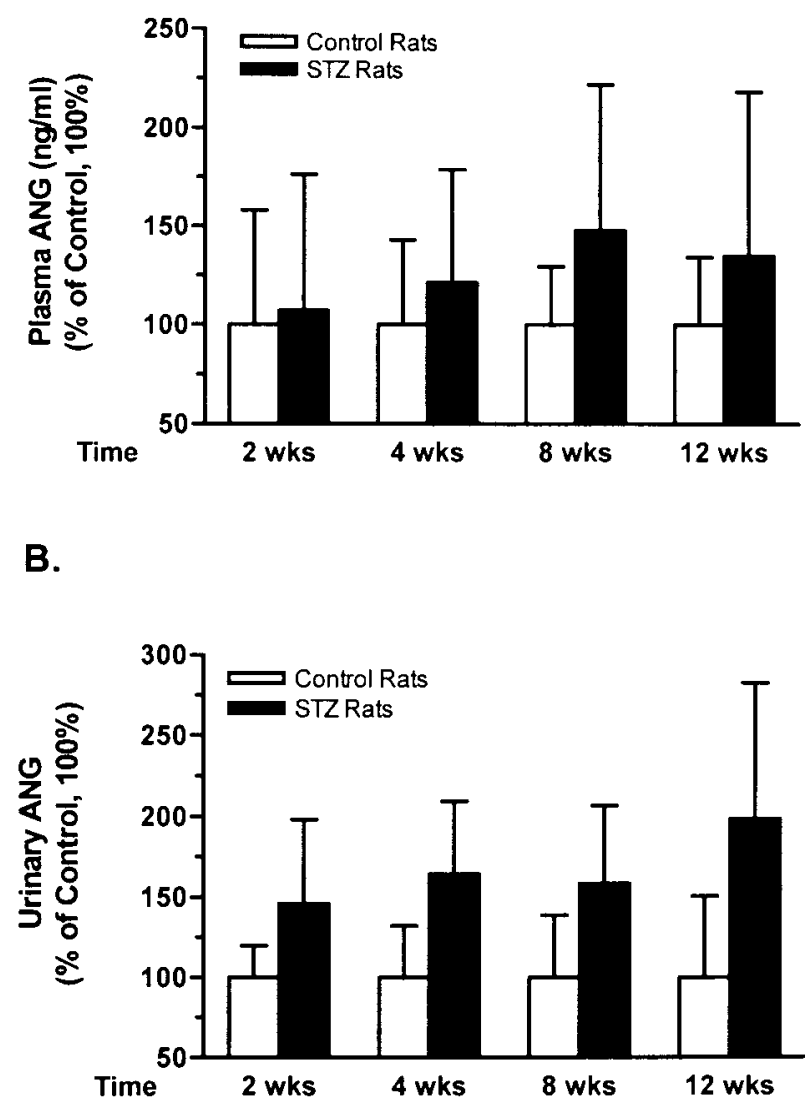

(POST-STZ ADMINISTRATION)

Figure 2 (A) Plasma and (B) urinary immunoreactive rat angiotensinogen (IR-rANG) levels in control and STZ rats. Values in normal rats are expressed as $100 \%$. Each point represents the mean \pm S.D. of 18 animals.

These studies demonstrate that the stimulatory action of glucose and the inhibitory influence of insulin on ANG gene expression were abolished in diabetic rat RPTCs.

Effect of high glucose and insulin on p44/42 MAPK phosphorylation in rat RPTCs

Insulin stimulated p44/42 MAPK phosphorylation in control rat RPTCs (Fig. 6), and the addition of PD 98059 $\left(10^{-5} \mathrm{M}\right)$ inhibited this effect. In contrast, insulin did not stimulate p44/42 MAPK phosphorylation in diabetic rat RPTCs (Fig. 7). These studies demonstrate that hyperglycaemia alters insulin signalling on p44/42 MAPK phosphorylation in diabetic rat RPTCs. 
(A)

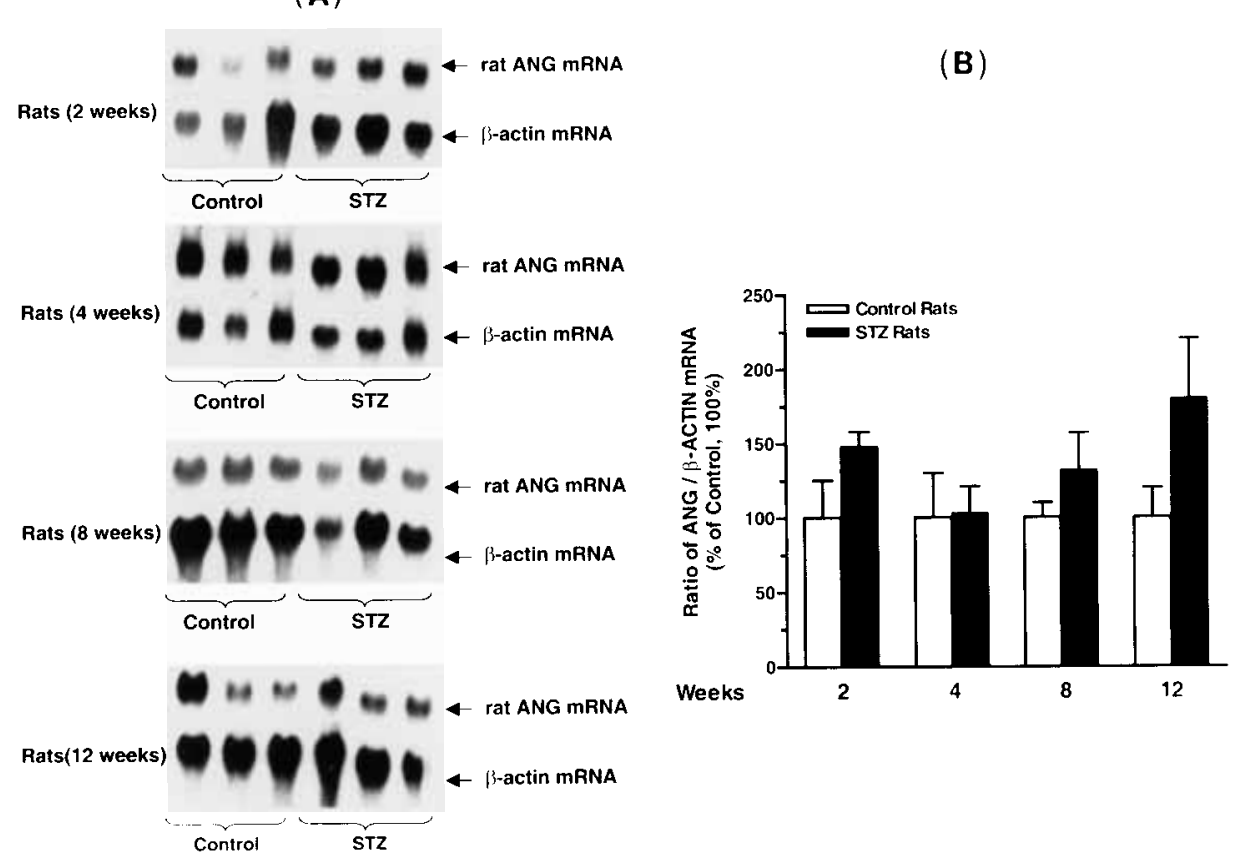

Figure 3 (A) Northern blot analysis of whole kidney ANG mRNA and $\beta$-actin mRNA in non-diabetic (control) and STZ rats. Total RNAs from rat kidney $(30 \mu \mathrm{g})$ were separated by agarose gel electrophoresis and transferred to a Hybond-N nylon membrane. The membrane was hybridized with ${ }^{32}$ P-labelled rat ANG CDNA probes for the rat ANG gene. The same blot was also hybridized with ${ }^{32}$ P-labelled hamster $\beta$-actin cDNA probes to standardize the amount of total RNA used. (B) The relative densities of the ANG band were compared with the $\beta$-actin control. The ANG mRNA level in control rats is considered as $100 \%$. Each point represents the mean \pm S.D. of 3 rats. Similar results were obtained from two other experiments.

Effect of high glucose and insulin on $A N G m R N A$ in rat RPTCs

Figure 8 shows the optimal number of cycles of PCR for the amplification of ANG and $\beta$-actin cDNA fragments from rat RPTCs. It is apparent that 35 and 30 cycles of PCR are optimal to amplify the ANG and $\beta$-actin cDNA fragments, respectively, from rat RPTCs. These optimized conditions were subseqently used in all experiments.

Figure 9 shows that high glucose concentrations (25 mM) stimulated ANG mRNA accumulation in control rat RPTCs. ANG mRNA levels were two-fold higher than in control cells cultured in medium containing $5 \mathrm{mM}$ glucose $(P \leq 0 \cdot 05)$. Insulin $\left(10^{-7} \mathrm{M}\right)$ completely inhibited the stimulatory effect of high glucose $(25 \mathrm{mM})$ on ANG mRNA levels in control rat RPTCs. PD 98059 blocked the suppressive effect of insulin. In contrast, high glucose and insulin had no influence on ANG mRNA accumulation in 2-week post-STZ-D rat RPTCs (Fig. 10). PD 98059 had no effect on ANG mRNA levels in diabetic rat RPTCs incubated in $25 \mathrm{mM}$ glucose medium with insulin.

\section{Discussion}

The major finding of this study is that prolonged hyperglycaemia is associated with insulin resistance on ANG gene expression in diabetic rat RPTCs. This attenuation of the insulin action appears to be due to a defect(s) in the p44/42 MAPK signal transduction pathway.

In the present studies, we observed increased kidney to body weight ratios and elevated plasma glucose levels in STZ-D rats (Fig. 1), features characteristic of STZinduced diabetes (Anderson et al. 1993, Kalinyak et al. 1993, Shankland \& Scholey 1995, Osicka et al. 2000, Zimpelmann et al. 2000). Plasma IR-rANG levels increased after 4 weeks of diabetes (Fig. 2), but did not reach statistical significance compared with the controls. These findings are consistent with other reports that plasma Ang II levels in diabetic rats are not statistically different from those in non-diabetic controls (Zimpelmann et al. 2000). Conflicting results from different groups have, however, been reported on the expression of renal RAS genes in experimental diabetes mellitus. Correa-Rother et al. (1992) found that whole kidney renin 


\section{A. Rats(2 wks)}

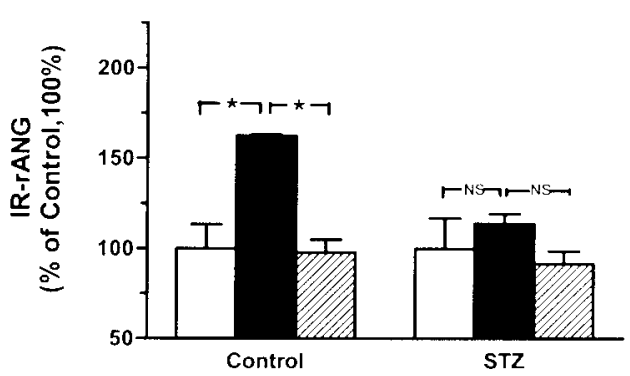

C. Rats $(8 \mathrm{wks})$

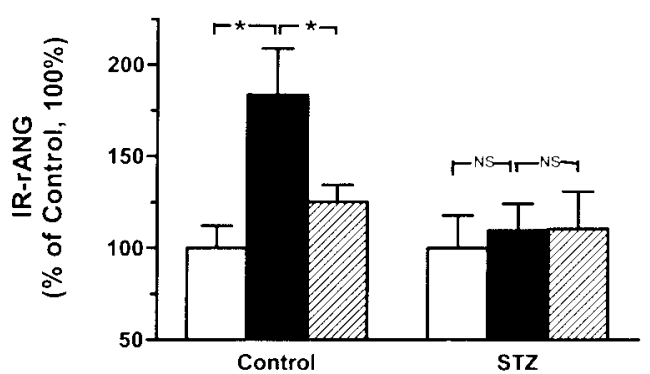

B. Rats (4 wks)

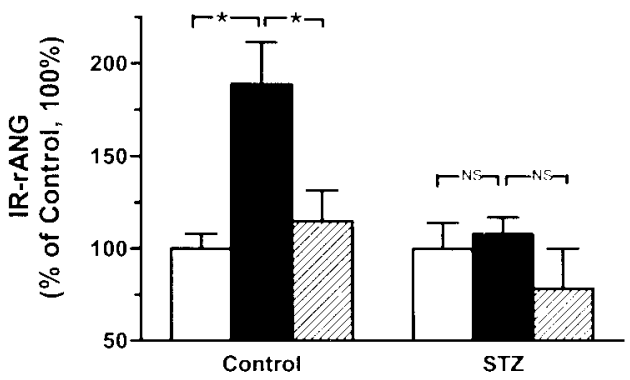

D. Rats (12 wks)

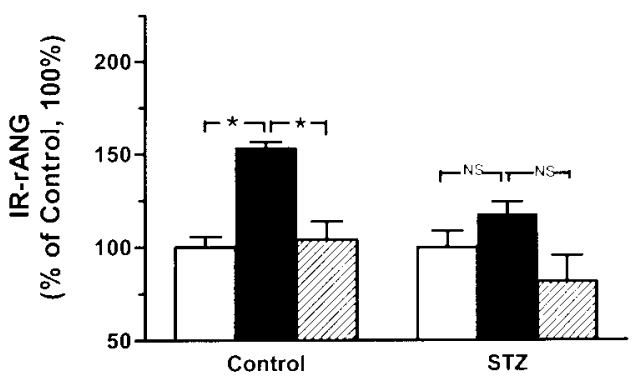

Figure 4 Effect of high glucose and insulin on IR-rANG secretion from control and 2, 4, 8 and 12-week STZ rat renal proximal tubular cells (RPTCs). The cells were incubated for $24 \mathrm{~h}$ in the presence of $5 \mathrm{mM}$ glucose, $25 \mathrm{mM}$ glucose, or $25 \mathrm{mM}$ glucose plus $10^{-7} \mathrm{M}$ insulin. The media were harvested and assayed for IR-rANG. IR-rANG levels in medium containing $5 \mathrm{mM}$ glucose are expressed as $100 \%$ (control). The inhibitory effect of insulin is compared with cells incubated with $25 \mathrm{mM}$ glucose (without insulin). The results are expressed as the percentage of controls (mean \pm S.D., $n=6$ ). ${ }^{*} P \leq 0 \cdot 05$; NS, not significant. Open bars, cells cultured in $5 \mathrm{mM}$ glucose medium without insulin; solid bars, cells cultured in $25 \mathrm{mM}$ glucose medium without insulin; hatched bars, cells cultured in $25 \mathrm{mM}$ glucose medium plus $10^{-7} \mathrm{M}$ insulin. Similar results were obtained in two other experiments.

protein and mRNA expression were not different between 4-week diabetic and control animals, but ANG mRNA levels were slightly lower in the diabetic groups. Kalinyak et al. (1993) reported that there were no significant differences in the expression of whole kidney renin and ANG mRNA in rats 2 weeks after the induction of diabetes compared with controls. In contrast, Anderson et al. (1993) demonstrated a small increment in renal proximal tubular ANG and renin gene expression in rats 6 to 8 weeks after the induction of diabetes as well as augmented ACE immunostaining in renal glomeruli and vascular vessels. Everett et al. (1992) reported an increase in ANG immunostaining but not in ANG mRNA in the proximal tubules of Biobreeding (BB) spontaneously diabetic rats after 4 and 8 months. More recent studies by Choi et al. (1997) and Zimpelmann et al. (2000) indicated that renin mRNA expression but not ANG and ACE mRNA expression was increased in 2-week diabetic rat renal proximal tubules. Our studies showed no significant difference in total kidney ANG mRNA expression in diabetic rats 2, 4, 8 and 12 weeks after STZ administration compared with the controls (Fig. 3). While there is no clear explanation for these apparently conflicting results on the expression of renal ANG and renin mRNA, the difference might be attributed to the duration of diabetes and the diverse strains of experimental rats used by these various investigators. Furthermore, differences in the conditions of isolation of proximal tubules (e.g. presence of normal glucose concentrations in buffers) might have caused acute changes in ANG or ACE mRNA expression.

Our studies showed that IR-rANG secretion from control rat RPTCs (Fig. 4) was increased by $1 \cdot 5$-fold in high glucose $(25 \mathrm{mM})$ medium compared with normal glucose $(5 \mathrm{mM})$ medium. This level of stimulation is similar to that observed in our previous studies which revealed that a high level of glucose $(25 \mathrm{mM})$ augmented rat ANG gene expression by 1.5 -fold in opossum kidney (OK) cells (Wang et al. 1998) and IRPTCs (Zhang et al. 1999a,b, 2001). We have also demonstrated that insulin inhibited the stimulatory effect of glucose on IR-rANG secretion from control rat RPTCs (Fig. 4). These results are consistent with our previous report that insulin inhibits IR-rANG secretion from IRPTCs in a dose-dependent manner with a maximal effect at $10^{-7} \mathrm{M}$ (Zhang et al. 1999b). Our data are also in agreement with the studies of Chang and Perlman (1988) who observed that insulin attenuated ANG mRNA expression in rat hepatoma cells in vitro, and with the studies of Aubert et al. (1998) who 
(A)

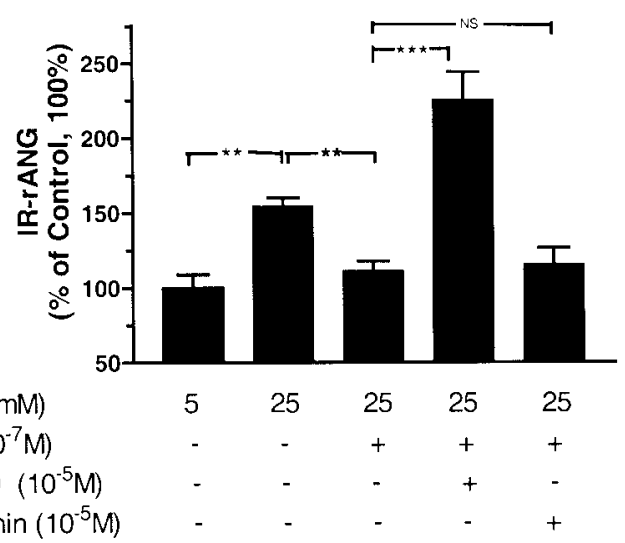

(B)

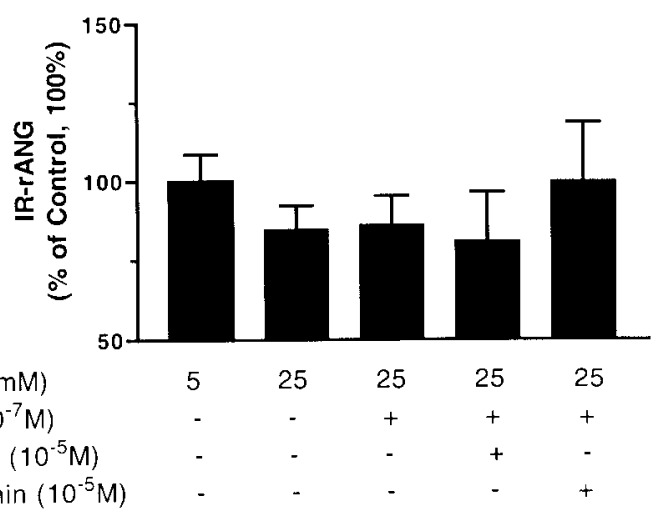

$$
\begin{aligned}
& \text { Glucose }(\mathrm{mM}) \\
& \text { Insulin }\left(10^{-7} \mathrm{M}\right) \\
& \text { PD } 98059\left(10^{-5} \mathrm{M}\right) \\
& \text { Wortmannin }\left(10^{-5} \mathrm{M}\right)
\end{aligned}
$$

Figure 5 Effect of PD 98059 and Wortmannin on IR-rANG secretion from (A) control and (B) 2-week STZ rat RPTCs. The cells were incubated for $24 \mathrm{~h}$ in the presence of $5 \mathrm{mM}$ glucose, $25 \mathrm{mM}$ glucose, $25 \mathrm{mM}$ glucose plus $10^{-7} \mathrm{M}$ insulin or $25 \mathrm{mM}$ glucose plus $10^{-7} \mathrm{M}$ insulin and $10^{-5} \mathrm{M}$ PD 98059 or $10^{-5} \mathrm{M}$ Wortmannin. The media were assayed for IR-rANG. IR-rANG levels in medium containing $5 \mathrm{mM}$ glucose are expressed as $100 \%$ (control, $5 \cdot 7 \pm 0 \cdot 2 \mathrm{ng} / \mathrm{ml} / 10^{6}$ cells in non-diabetic RPTCs and $4 \cdot 6 \pm 0 \cdot 8 \mathrm{ng} / \mathrm{ml} / 10^{6}$ cells in diabetic RPTCs). The effect of PD 98059 or Wortmannin was compared with cells incubated with $25 \mathrm{mM}$ glucose in the presence of insulin. The results are expressed as the percentage of controls (mean \pm S.D., $n=3$ ). ${ }^{* *} P \leq 0 \cdot 01,{ }^{* *} P \leq 0 \cdot 005$; NS, not significant. Similar results were obtained in two other experiments.

showed that insulin down-regulated ANG gene expression and secretion in cultured adipose tissue. Taken together, these results suggest that insulin down-regulates ANG gene expression at the transcription level. Indeed, our most recent studies have demonstrated that insulin inhibits the activity of the ANG gene promoter in proximal tubular cells (Wu et al. 2000, Chen et al. 2001).

Surprisingly, we did not find any significant change in IR-rANG secretion by high glucose level $(25 \mathrm{mM})$ or insulin $\left(10^{-7} \mathrm{M}\right)$ in diabetic rat RPTCs (Figs 4 and $5 \mathrm{~B}$ ). These studies suggest that the signalling pathways for
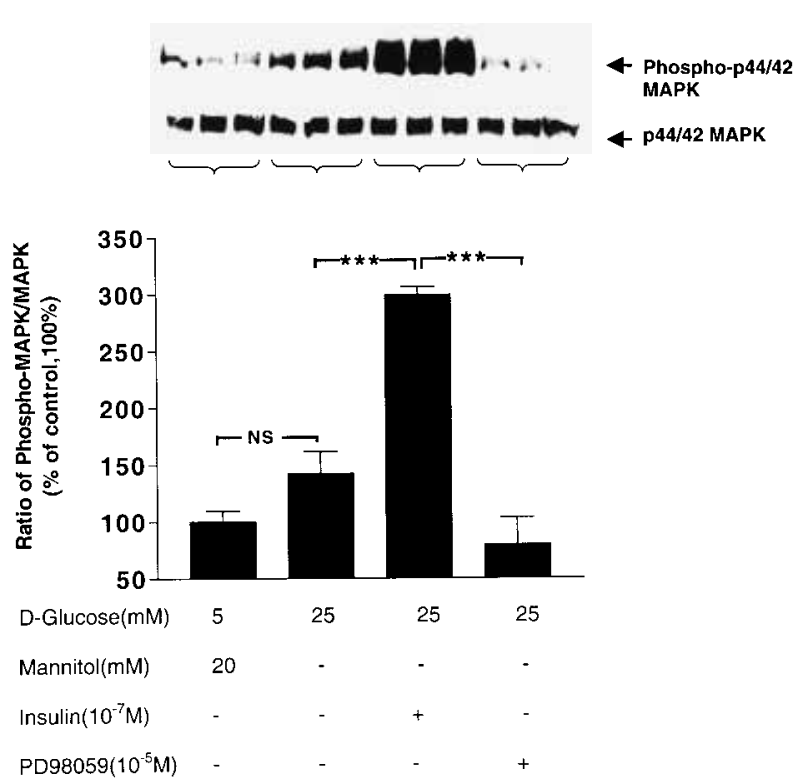

Figure 6 Effect of high glucose and insulin on p44/42 MAPK phosphorylation in control rat RPTCs. After $24 \mathrm{~h}$ incubation in $5 \mathrm{mM}$ glucose, the cells were incubated in $5 \mathrm{mM}$ glucose, $25 \mathrm{mM}$ glucose, or $25 \mathrm{mM}$ glucose plus PD 98059 for $15 \mathrm{~min}$. Then, insulin $\left(10^{-7} \mathrm{M}\right)$ was added and the cells were incubated for a further $10 \mathrm{~min}$. The cells were then harvested and assayed for phosphorylated p44/42 MAPK and total p44/42 MAPK with the PhosphoPlus p44/42 MAPK antibody kit (upper panel). The ratio of relative densities of phosphorylated p44/42 MAPK to total p44/42 MAPK in cells incubated in $5 \mathrm{mM}$ glucose DMEM was considered as $100 \%$ (control) (lower panel). Each point represents the mean \pm S.D. of 3 dishes. ${ }^{* \star *} P \leq 0 \cdot 005$; NS, not significant. Similar results were obtained in two other experiments.

glucose and insulin might be altered in diabetic rat RPTCs.

At present, we do not understand the exact molecular mechanism(s) for the lack of stimulatory effect of high glucose on ANG gene expression in diabetic rat RPTCs. One possible explanation is that chronic exposure of animals to high glucose (hyperglycaemia) or other regulatory factors may desensitize the PKC signalling pathway that mediates the stimulatory action of high glucose. Indeed, this possibility is supported by our previous observation that overnight pre-incubation of opossum kidney $(\mathrm{OK})$ proximal tubular cells with high glucose $(25 \mathrm{mM})$ or phorbal 12-myristate 13-acetate (PMA) $\left(10^{-5} \mathrm{M}\right)$ abolishes the stimulatory effect of $25 \mathrm{mM}$ glucose on the expression of ANG gene promoter activity (Wang et al. 1998). Similarly, we have shown that overnight pre-incubation of rat immortalized renal proximal tubular cells (IRPTCs) with high PMA $\left(10^{-5} \mathrm{M}\right)$ abolishes the stimulatory action of a low dose of PMA $\left(10^{-7} \mathrm{M}\right)$ on IR-rANG secretion (Zhang et al. 1999a). Nevertheless, more experiments are warranted to clarify these observations. 

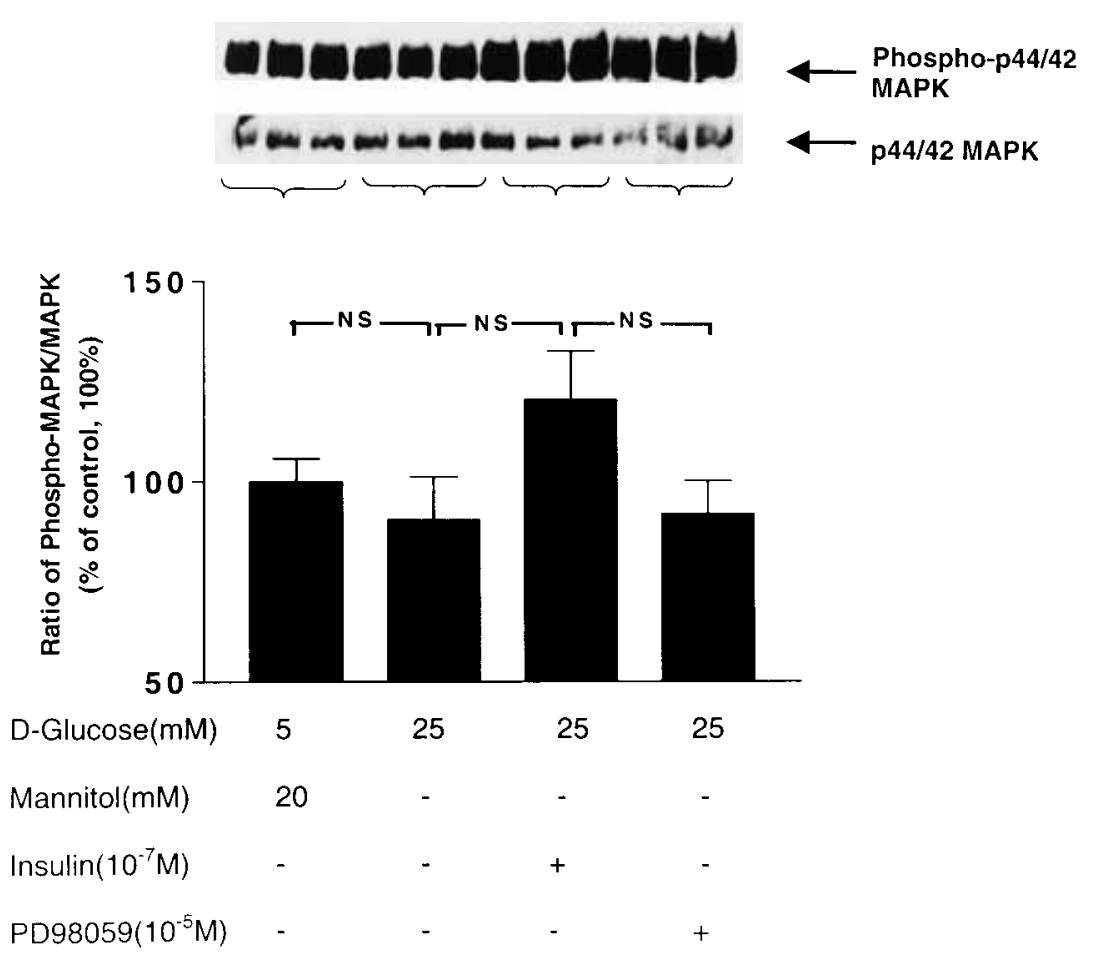

Figure 7 Effect of high glucose and insulin on p44/42 MAPK phosphorylation in 2-week diabetic rat RPTCs. After $24 \mathrm{~h}$ incubation in $5 \mathrm{mM}$ glucose, the cells were incubated in $5 \mathrm{mM}$ glucose, $25 \mathrm{mM}$ glucose, or $25 \mathrm{mM}$ glucose plus PD 98059 for $10 \mathrm{~min}$. Then, insulin $\left(10^{-7} \mathrm{M}\right)$ was added, and the cells were further incubated for $15 \mathrm{~min}$. The cells were harvested and assayed for phosphorylated p44/42 MAPK and total p44/42 MAPK with the PhosphoPlus p44/42 MAPK antibody kit (upper panel). The ratio of relative densities of phosphorylated p44/42 MAPK to total p44/42 MAPK in cells incubated in $5 \mathrm{mM}$ glucose DMEM was considered as $100 \%$ (control) (lower panel). Each point represents the mean \pm S.D. of 3 dishes. NS, not significant. Similar results were obtained in two other experiments.

We were equally surprised that the addition of insulin had no influence on IR-rANG secretion from RPTCs isolated from rats with established diabetes (Figs 4 and $5 \mathrm{~B}$ ). We detected insulin resistance as early as 2 weeks post STZ treatment. Previously we reported that insulin $\left(10^{-7} \mathrm{M}\right)$ inhibits the stimulatory effect of $25 \mathrm{mM}$ glucose on IR-rANG secretion and ANG mRNA expression in IRPTCs via the p44/42 MAPK signalling pathway (Zhang et al. 1999b). These observations raise the possibility that the action of insulin on the p44/42 MAPK signalling pathway might be attenuated. Indeed, our results showed that insulin stimulates the phosphorylation of p44/42 MAPK in non-diabetic RPTCs (Fig. 6), and PD $98059\left(10^{-5} \mathrm{M}\right.$ ) (an inhibitor of MAPK kinase (MEK)) (Pang et al. 1995) inhibited this effect. In contrast, insulin did not stimulate p44/42 MAPK phosphorylation in diabetic rat RPTCs (Fig. 7). Morever, Wortmannin (an inhibitor of phosphatidylinositol-3-kinase) (Nakamura et al. 1995) did not affect insulin action on p44/42 MAPK phosphorylation in normal and diabetic rat RPTCs (unpublished results). These studies suggest that the defect(s) in insulin signalling on MAPK phosphorylation in diabetic rat RPTCs may be located upstream of MAPK phosphorylation, i.e. the activation of insulin receptor substrate (IRS)-1/2 or Ras or Raf-1. Indeed, work is underway in our laboratory to identify the defect(s) in the MAPK signal transduction pathway. In addition, it remains to be investigated whether culture of tubular cells from diabetic rats for prolonged times in normal glucose, or treatment of the diabetic animals with insulin to achieve normal or slightly elevated plasma glucose could restore the insulin sensitivity of the ANG gene.

In this study, we compared the relative amount of ANG and $\beta$-actin mRNA expression in rat RPTCs. Our studies showed that there is a linear relationship between the number of PCR cycles and the amount of ANG and $\beta$-actin cDNA fragments generated (Fig. 8). It is apparent that 35 and 30 cycles of PCR are the optimal conditions to amplify the ANG and $\beta$-actin cDNAs, respectively, from rat RPTCs. These conditions were used in subsequent experiments. 
(A)

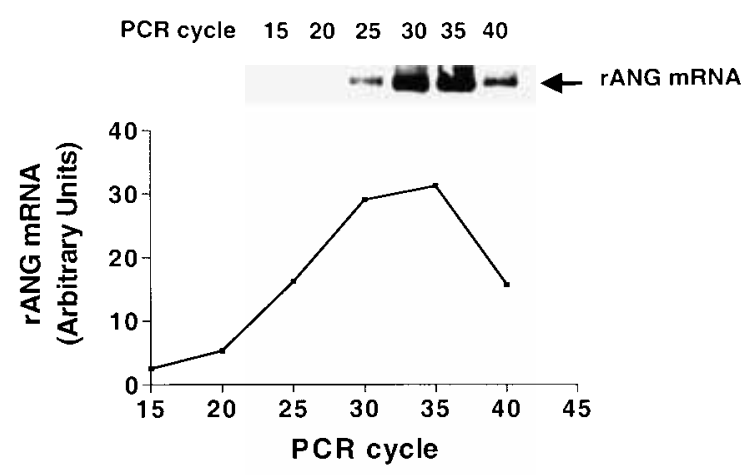

(B)

$\begin{array}{lllllll}\text { PCR cycle } & 15 & 20 & 25 & 30 & 35 & 40\end{array}$
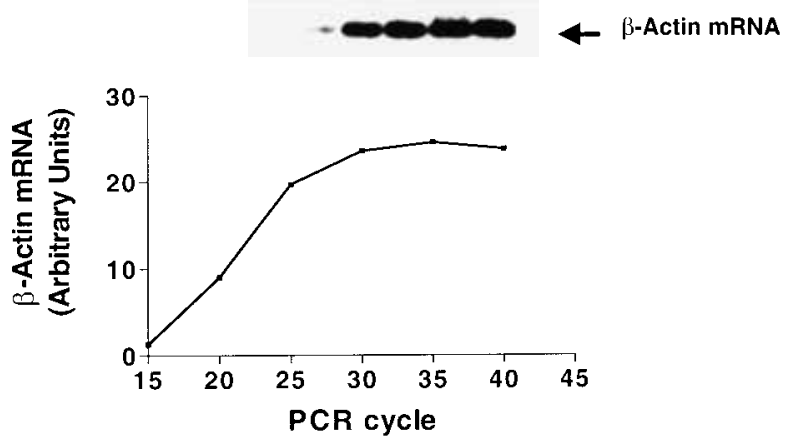

Figure 8 RT-PCR of the ANG and $\beta$-actin mRNA followed by Southern blot analysis from rat RPTCs. Two microlitres first strand cDNA reaction mixture were used to amplify the ANG or $\beta$-actin cDNA fragment from 15 to 40 cycles of PCR. Then, $10 \mu \mathrm{l} \mathrm{PCR}$ products were separated on $1.5 \%$ agarose gel and then transferred onto a Hybond-XL nylon membrane. Subsequently, the membrane was blotted with a ${ }^{32} \mathrm{P}$-labelled oligonucleotide corresponding to the nucleotide sequences $\mathrm{N}+775$ to $\mathrm{N}+798$ of rat ANG and $N+9$ to $N+35$ of exon 4 of rat $\beta$-actin respectively. The relative density of the PCR band of ANG or $\beta$-actin at various PCR cycles was compared with that obtained at 15 PCR cycles.

It is evident that the effects of glucose and insulin on ANG gene expression occur at the mRNA level. Exposure of control rat RPTCs (Fig. 9) to high glucose concentration $(25 \mathrm{mM})$ significantly stimulated ANG mRNA expression (a two-fold increase) compared with cells cultured in $5 \mathrm{mM}$ glucose medium. Insulin $\left(10^{-7} \mathrm{M}\right)$ completely blocked the stimulatory effect of $25 \mathrm{mM}$ glucose. PD 98059 reversed the inhibitory action of insulin. In contrast, neither high glucose $(25 \mathrm{mM})$ nor insulin $\left(10^{-7} \mathrm{M}\right)$ had any influence on ANG mRNA expression in diabetic rat RPTCs (Fig. 10). Moreover, we found that there was no significant difference in basal ANG mRNA expression between control and diabetic RPTCs (unpublished results). At present, it is uncertain whether high glucose or insulin affects ANG mRNA
(A)

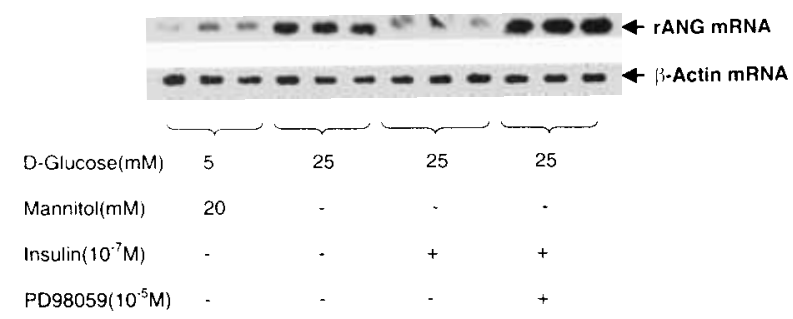

(B)

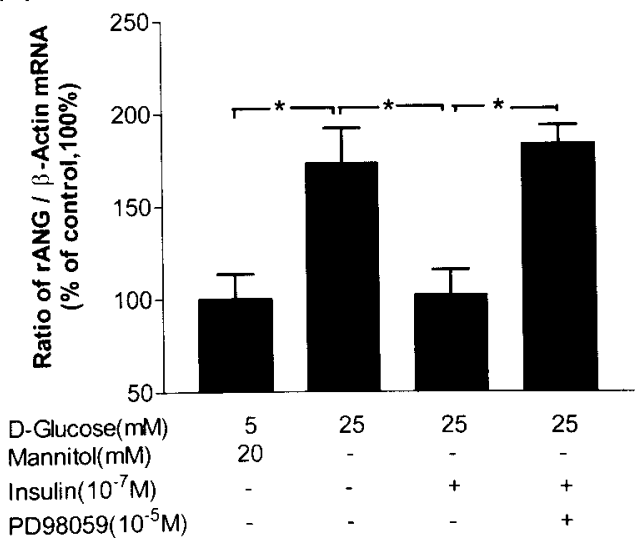

Figure 9 Effect of glucose and insulin on rat ANG mRNA expression in control rat RPTCs. After $24 \mathrm{~h}$ incubation in media with $5 \mathrm{mM}$ glucose, $25 \mathrm{mM}$ glucose, or $25 \mathrm{mM}$ glucose plus insulin $\left(10^{-7} \mathrm{M}\right)$ in the absence or presence of PD 98059 $\left(10^{-5} \mathrm{M}\right)$, the cells were harvested and assayed for ANG mRNA levels by RT-PCR assay. DNA fragments of the RT-PCR mixture were separated on $1.5 \%$ agarose gel and then transferred onto a Hybond-XL nylon membrane. Subsequently, the membrane was blotted with a ${ }^{32} \mathrm{P}$-labelled oligonucleotide corresponding to the nucleotide sequences $\mathrm{N}+775$ to $\mathrm{N}+798$ of rat $\mathrm{ANG}$ and $\mathrm{N}+9$ to $\mathrm{N}+35$ of exon 4 of rat $\beta$-actin respectively (A). The relative density of the PCR band of ANG was compared with the $\beta$-actin control (B). The rANG mRNA level in cells normalized in $5 \mathrm{mM}$ glucose was considered as $100 \%$ (control). Each point represents the mean \pm S.D. of 3 dishes. ${ }^{\star} P \leq 0 \cdot 05$.

levels at the transcriptional level or the stability of ANG mRNA in rat RPTCs. Studies are ongoing in our laboratory to investigate these possibilities.

In summary, our studies demonstrate that exposure of non-diabetic rat RPTCs to $25 \mathrm{mM}$ glucose directly stimulated rat ANG gene expression. The stimulatory effect of high glucose was blocked by insulin via the p44/42 MAPK signalling transduction pathway. In contrast, the stimulatory and inhibitory actions of high glucose and insulin, respectively, on ANG gene expression were abolished in diabetic rat RPTCs. Furthermore, we have demonstrated that the $\mathrm{p} 44 / 42$ MAPK signal transduction pathway is altered in diabetic rat RPTCs. These findings raise the possibility that restoration of insulin sensitivity on renal ANG gene expression might be an important step for 
(A)

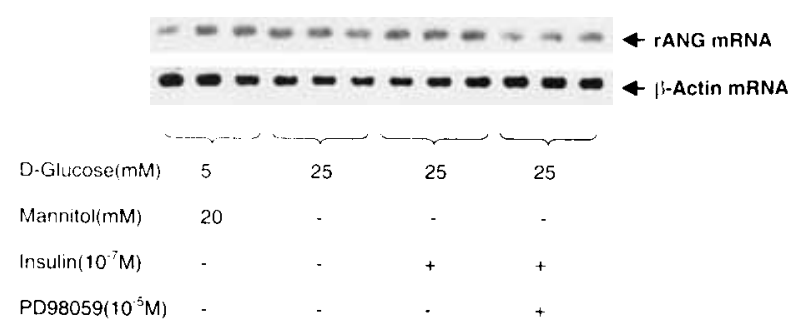

(B)

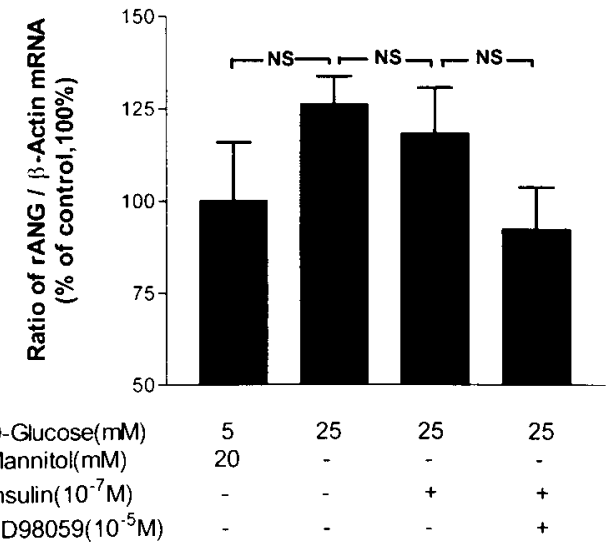

Figure 10 Effect of glucose and insulin on rat ANG mRNA expression in 2-week diabetic rat RPTCs. After $24 \mathrm{~h}$ incubation in media with $5 \mathrm{mM}$ glucose, $25 \mathrm{mM}$ glucose, or $25 \mathrm{mM}$ glucose plus insulin $\left(10^{-7} \mathrm{M}\right)$ in the absence or presence of PD 98059 $\left(10^{-5} \mathrm{M}\right)$, the cells were harvested and assayed for ANG mRNA levels by RT-PCR assay as described in Fig. 9. NS, not significant.

insulin to inhibit the activation of the local renal RAS. Subsequently, the suppression of renal RAS by insulin may prevent the renal hypertrophy observed in early diabetes. This approach should be explored further rather than treatment with insulin alone in insulin-dependent diabetic patients.

\section{Acknowledgements}

This work was supported by grants from the Kidney Foundation of Canada (J S D C and J P H), the Medical Research Council of Canada (MT-13420 to J S D C, MT-15070 to JSDC and J GF, and MT-12573 to JGF) and the National Institutes of Health of USA (HL-48455 to J R I and DK-50836 to S S T). The authors thank Mrs Ilona Schmidt for her secretarial assistance and Mr Ovid M Da Silva, Éditeur-Rédacteur, Bureau d'aide à la recherche, Research Center, CHUM, for editing this manuscript.

\section{References}

Anderson S, Jung FF \& Ingelfinger JR 1993 Renal renin-angiotensin system in diabetes. Functional immunohistochemical, and molecular biological correlations. American Journal of Physiology 265 F477-F486.

Aubert J, Safanova I, Negrel R \& Ailhaud G 1998 Insulin downregulates angiotensinogen gene expression and angiotensinogen secretion in cultured adipose cells. Biochemical and Biophysical Research Communications 250 77-82.

Bakris GL 1993 Angiotensin-converting enzyme inhibitors and the progression of diabetic nephropathy. Annals of Internal Medicine $\mathbf{1 1 8}$ 643-644

Chang E \& Perlman AJ 1988 Angiotensinogen mRNA regulation by cell cycle and growth factors. Journal of Biological Chemistry 263 $5480-5484$.

Chen M, Harris MP, Rose D, Smart A, He X-R, Kretzler M, Briggs JP \& Schnermann J 1994 Renin and renin mRNA in proximal tubule of the rat kidney. Journal of Clinical Investigation 94 237-243.

Chen X, Zhang S-L, Pang L, Filep JG, Tang S-S, Ingelfinger JR \& Chan JSD 2001 Characterization of a putative insulin-responsive element and its binding protein(s) in rat angiotensinogen gene promoter: regulation by glucose and insulin. Endocrinology 142 $2577-2585$.

Choi KC, Kim NH, An MR, Kang DG, Kim SW \& Lee J-U 1997 Alterations in intrarenal renin-angiotensin and nitric oxide systems in streptozotocin-induced diabetic rats. Kidney International $\mathbf{5 2}$ 523-527.

Chung SD, Alavi N, Livingston D, Hiller S \& Taub M 1982 Characterization of primary rabbit kidney cultures that express proximal tubule function in a hormonally defined medium. Journal of Cell Biology 95 118-126.

Correa-Rotter R, Hostetter TH \& Rosenberg ME 1992 Renin and angiotensinogen gene expression in experimental diabetes. Kidney International 41 796-804.

Everett AD, Scott J, Wilfong N, Marino B, Rosenkranz RP, Inagami T \& Gomez RA 1992 Renin and angiotensinogen expression during the evolution of diabetes. Hypertension 19 70-78.

Gandhi SK, Ryder DH \& Brown NJ 1996 Losartan blocks aldosterone and renal vascular responses to angiotensin II in humans. Hypertension 28 961-966.

Ichikawa I 1996 Will angiotensin II receptor antagonists be renoprotective in humans? Kidney International 50 684-692.

Ingelfinger JR, Zuo WM, Fon EA, Ellison KE \& Dzau VJ 1990 In situ hybridization evidence for angiotensinogen mRNA in the rat proximal tubule. A hypothesis for the intrarenal renin angiotensin system. Journal of Clinical Investigation 85 417-423.

Ingelfinger JR, Jung F, Dramant D, Haveran L, Lee E, Brem A \& Tang S-S 1999 Rat proximal tubule cell line transformed with origin-defective SV40 DNA: autocrine Ang II feedback. American Journal of Physiology 276 (Renal Physiology 45) F218-F227.

Kalinyak JE, Sechi LA, Griffon CA, Don BR, Tavangar K, Kraemer FB, Hoffman AR \& Schambelan M 1993 The renin-angiotensin system in streptozotocin-induced diabetes mellitus in the rat. Journal of the American Society for Nephrology 4 1337-1345.

Lewis EJ, Hunsicker LG, Bain KP \& Rhode RD 1993 The effect of angiotensin-converting enzyme inhibition on diabetic nephropathy. New England Journal of Medicine 329 1456-1462.

Loghman-Adham M, Rohrwasser A, Helin C, Zhang S, Terreros D, Inoue I \& Lalouel J-M 1997 A conditionally immortalized cell line from murine proximal tubule. Kidney International 52 229-239.

Maurer SM 1994 Structure-functional correlations of diabetic nephropathy. Kidney International 45 612-622.

Nakamura I, Takahashi N, Sasaki T, Tanaka S, Udagawa N, Murakami H, Kimura K, Kabuyama Y, Kurokawa T, Suda T \& Fukui Y 1995 Wortmannin, a specific inhibitor of phosphatidylinositol-3 kinase, blocks osteoclastic bone resorption. FEBS Letters 361 79-84. 
Nudel U, Zakut R, Shani M, Neuman S, Levy Z \& Yaffe D 1983

The nucleotide sequence of the rat cytoplasmic $\beta$-actin gene. Nucleic Acids Research 11 1759-1771.

Ohkubo H, Kageyama R, Ujihara M, Hirose T, Inayama S \& Nakanishi S 1983 Cloning and sequence analysis of cDNA for rat angiotensinogen. PNAS 80 2196-3000.

Osicka TM, Yu Y, Panagiotopoulos S, Clavant SP, Kiriazis Z, Pike RN, Pratt LM, Russo LM, Kemp BE, Comper WD \& Jerums G 2000 Prevention of albuminuria by aminoguanidine or ramipril in streptozotocin-induced diabetic rats is associated with the normalization of glomerular protein kinase C. Diabetes 49 87-93.

Pang L, Sawad T, Decker SJ \& Saltiel AR 1995 Inhibition of MAP kinase kinase blocks the differentiation of $\mathrm{P} 12$ cells induced by nerve growth factor. Journal of Biological Chemistry $\mathbf{2 7 0}$ 13585-13588.

Rocco M, Chen Y, Goldfarb S \& Ziyadeh FN 1992 Elevated glucose stimulates TGF- $\beta$ gene expression and bioactivity in proximal tubule. Kidney International 41 107-114.

Ruilope LM 1997 Renoprotection and renin-angiotensin system blockade in diabetes mellitus. American Journal of Hypertension 10 325S-331S.

Samuels HH, Standby F \& Shapiro LE 1979 Control of growth hormone synthesis in cultured GH cells by $3,5,3^{\prime}$-triiodoL-thyronine and glucocorticoid agonists and antagonists: studies on the independent and synergistic regulation of the growth hormone response. Biochemistry 18 715-721.

Shankland SJ \& Scholey JW 1995 Expression of growth-related proto-oncogenes during diabetic renal hypertrophy. Kidney International 47 782-788.

Umezu M, Tang S-S, Chan JSD \& Ingelfinger JR 2000 Angiotensinogen is glycosylated and secreted from renal proximal tubular cells. Journal of the American Society for Nephrology 11 A2256 (Abstract).

Vinay P, Gougoux A \& Lemieux G 1981 Isolation of a pure suspension of rat proximal tubules. American Journal of Physiology 241 F403-F411.

Wang L, Lei C, Zhang S-L, Roberts KD, Tang S-S, Ingelfinger JR \& Chan JSD 1998 Synergistic effect of dexamethasone and isoproterenol on the expression of angiotensinogen in immortalized rat proximal tubular cells. Kidney International 53 287-295.

Wang TT, Wu X-H, Zhang SL \& Chan JSD 1998 The effect of glucose on the expression of angiotensinogen gene in opossum kidney cells. Kidney International 53 312-319.

Wolf G \& Neilson EG 1990 Angiotensin II induces cellular hypertrophy in cultured murine tubular cells. American Journal of Physiology 259 F768-F777.

Wolf G \& Neilson EG 1993 Angiotensin II as a hypertrophogenic cytokine for proximal tubular cells. Kidney International 43 (Suppl 39) S100-S107.
Wolf G \& Thaiss F 1995 Hyperglycemia: pathophysiological aspects at the cellular level. Nephrology, Dialysis, Transplantation 10 1109-1112.

Wolf G, Killen PD \& Neilson EG 1991a Intracellular signalling of transcription and secretion of type IV collagen after angiotensin II-induced cellular hypertrophy in cultured proximal tubular cells. Cell Regulation 2 219-227.

Wolf G, Neilson EG, Goldfarb S \& Ziyadeh FN $1991 b$ The influence of glucose concentration on angiotensin II-induced hypertrophy of proximal tubular cells in culture. Biochemical and Biophysical Research Communications 179 902-909.

Wolf G, Mueller E, Stahl RAK \& Ziyadeh FN 1993a Angiotensin II-induced hypertrophy of cultured murine proximal tubular cells is mediated by endogenous transforming growth factor- $\beta$. Journal of Clinical Investigation 92 1366-1372.

Wolf G, Zahner G, Mondorf U, Schoeppe W \& Stahl RAK 19936 Angiotensin II stimulates cellular hypertrophy of LLC-PK1 cells through the $\mathrm{AT}_{1}$ receptor. Nephrology, Dialysis, Transplantation $\mathbf{8}$ $128-133$.

Wu X-H, Chen X, Zhang S-L, Rag L, To C, Wang TT, Hohman TC, Filep JG \& Chan JSD 2000 Molecular mechanism(s) of insulin action on the expression of the angiotensinogen gene in kidney proximal tubular cells. Journal of Renin-Angiotensin-Aldosterone System 1 166-174.

Zhang S-L, Filep JG, Hohman TC, Tang S-S, Ingelfinger JR \& Chan JSD 1999a Molecular mechanisms of glucose action on angiotensinogen gene expression in rat proximal tubular cells. Kidney International 55 454-464.

Zhang SL, Chen X, Filep JG, Tang S-S, Ingelfinger JR \& Chan JSD $1999 b$ Insulin inhibits angiotensinogen gene expression via the mitogen-activated protein kinase pathway in rat kidney proximal tubular cells. Endocrinology 140 5285-5292.

Zhang SL, To C, Chen X, Filep JG, Tang S-S, Ingelfinger JR, Carriere S \& Chan JSD 2001 Effect of renin-angiotensin system blockade on the expression of the angiotensinogen gene and induction of hypertrophy in rat kidney proximal tubular cells. Experimental Nephrology 9 109-117.

Zimpelmann J, Kumar D, Levine DZ, Wehbi G, Imig JD, Navar LG \& Burns KD 2000 Early diabetes mellitus stimulates proximal tubule renin mRNA expression in the rat. Kidney International $\mathbf{5 8}$ 2320-2330.

Ziyadeh FN, Snipes ER, Watanabe M, Alvarez RJ, Goldfarb S \& Haverty TP 1990 High glucose induces cell hypertrophy and stimulates collagen gene transcription in proximal tubule. American Journal of Physiology 259 F704-F714.

Received 11 October 2001

Accepted 26 October 2001 